possibilities of a central award-giving body, and to advise the Minister in connexion with the forthcoming triennial review of awards. Mr. B. Vosper, Parliamentary Secretary to the Ministry of Education, declined to commit himself, but agreed that the problem is due for review. He said that the Minister is considering the probable effect of the projected university expansion on awards policy, but he sees no reason why the system of awards should fail to meet the proposed expansion, and he accepts the view that our policy should be to ensure that young persons desiring and capable of receiving university education should not be deprived of it. In 1955, he pointed out, 15,900 of the 18,000 United Kingdom students entering the English and Welsh universities held Ministry or local authority awards, and of these, 12,500 held local authority awards, an increase of 25 per cent on the figures for 1951. Moreover, every local authority has now come into line so far as awards and the basis of assessment are concerned, and there has been a considerable advance towards uniformity in vacation allowances and like matters. Complete uniformity has also been secured in regard to consideration of candidates with two passes in the General Certificate Examination at the advanced level.

\section{Scientific and Technical Co-operation in Africa}

AN admirable record of scientific and technical co-operation has been issued by the Commission for Technical Co-operation in Africa South of the Sahara and by the Scientific Council for Africa South of the Sahara, the secretariats of which were amalgamated on January 1, 1955, to ensure maximum co-ordination between two complementary organizations. In 1955 the Commission extended its interAfrican consultations to include the social sciences and convened the first meeting of the Inter-African Conference on the Mechanization of Agriculture as well as scientific meetings on the control of quelea birds and the use of irrigation water in drainage and agriculture. Recommendations have been submitted to member governments which may lead to the adoption of a standard system of meteorological and climatological data for the African continent, while studies have continued on strictly regional problems in soil conservation, land utilization and the scientific aspects of geology. The work of the two organizations to 1955 is reviewed in a series of chapters covering pedology, agriculture and forestry; meteorology, climatology, irrigation and drainage; physical hydrology ; animal resources; protection of natural resources and of agricultural production; geology; cartographic and statistical data; co-operation in the field of health; inter-African co-operation in social welfare and education; inter-African cooperation in the field of labour; joint action in the social sciences. They show that the activities of the Commission and of the Council now cover practically the whole scientific and technical field, while international contacts are also being widened. Chronological extracts from the annual reports of the Scientific Council for Africa, 1949-55, and from the technical conferences held under the rgis of the Commission, 1948-55, are also included, and there is a general index.

\section{Life-History of the Desert Locust}

"The Ruthless One", a new film on the desert locust made by the Shell Petroleum Co., Ltd., succeeds in the short screen time of $18 \mathrm{~min}$. in being equally interesting to the lay viewer and to the advanced student and teacher. The life-history of the desert locust is splendidly shown in colour, with close-up sequences of mating and egg-laying, and all stages of growth from the new hatchling to the winged adult. Since no amount of patient preparation can ensure demonstration of these processes on living material, this cannot fail to be of value to teachers. The nature and size of the locust problem are illustrated briefly, and some sequences made in the AntiLocust Research Centre in London show the work of that organization, particularly in the collection and dissemination of information. Some shots show research in the laboratory and in wind tunnels. With commendable self-effacement, the film does not deal at length with the practical achievements in field. methods of locust control. Scientists are inevitably divided in their attitude to all steps at popularization. The slightly melodramatic title is explained as a translation of $A l$ Garad, one of the Arabic names given to the locust. Then the question of musical background: Can the public never absorb information without it? However, it is well-composed music and anyone who has enjoyed, say, "Peter and the Wolf", will enjoy the background to the courtship scene. Issued in conjunction with the film is an illustrated booklet, "The Hungry Thief" ; this will help the layman-and perhaps the administrator-to understand the recent progress made in the locust problem.

\section{A New Reactor Course at Harwell}

NEw opportunities for industry to acquire basic knowledge of nuclear energy are offered by a special course which has been arranged at the Harwell Reactor School. The standard Reactor School course is one of fourteen weeks duration, giving instruction primarily in reactor physics and engineering. Present arrangements enable some students to attend only the first six weeks of this course, during which time the basic principles of these subjects are taught; but the numbers of these students have had to be limited because the demand for places on the standard course has been high.

During June 3-July 12, 1957, a special six weeks course is to be run entirely separately, and some sixty places will be available. Besides covering the basic principles of the physics and engineering of reactors, lectures will be given on such subjects as reactor metallurgy, shielding and health physics. In addition, emphasis will be placed on special topies such as the instrumentation of reactors and the use of radioisotopes in industry. This special course is designed primarily for people of degree standard who are not directly concerned with overall reactor design. It should appeal especially to members of firms whose interest lies in the making of ancillary equipment for reactors. Application forms can be obtained from the Reactor School, Atomic Energy Research Establishment, Harwell, Berkshire.

\section{Conference of Farm Historians}

Sir JAMES Scotr WATSON took the chair at the winter conference of the British Agricultural History Society held in December in co-operation with the Association of Agriculture at the Institute of Education, University of London. The conference listened to three papers : one by Mr. F. C. Payne, of the Welsh Folk Museum, St. Fagans, on "The Plough in Britain", and a second by Miss E. M. Marston, lecturer in horticulture at the University of Nottingham, on 